\title{
Family Centeredness in Mental Health: A Concept Analysis
}

https://doi.org/10.37719/jhcs.2020.v2i1.ra002

\author{
IRIL I. PANES, PhD, MA, RN \\ https://orcid.org/0000-0001-6687-3734
}

Sultan Kudarat State University, College of Health Sciences

Corresponding author's email: irilpanes@sksu.edu.ph

\begin{abstract}
Background: Mental illness affects the entire family structure. The family members are the main provider of care that results in caregiving burden. Thus, the care given should encompass the entire family system, termed as family centeredness.
\end{abstract}

Purpose: This study clarifies the concept of "family centeredness" in mental health to enhance individual and family cares living amid mental illness.

Methods: This research employed Walker and Avant's method of Concept Analysis. Literature was reviewed, and the characteristics that appeared repeatedly were noted and categorized. Data were mapped according to its definition, antecedents, attributes, and consequences.

Results: Three key defining attributes were identified: (a) A mutual, collaborative partnership between the patient, family and health care providers based on knowledge exchange, open communication and cooperation; (b) A supportive, professional relationship/bond/engagement among health care providers, patient and family characterized by empathy, understanding, respect and empowerment; and (c) Individualized care wherein the process is defined by the family is supported, enabling the opportunity to choose, control over decisions and empowerment.

Conclusion: The result of the study clearly defines family centeredness as a health care approach in mental health that acknowledges the patient and family as the experts on themselves, involves families as collaborative partners in all aspects of services and decisions about care through mutually beneficial supportive partnerships with health care providers; to help patients make progress towards recovery. 
Keywords: Family, Family-centered care, Mental Health, Mental illness

\section{Introduction}

amily denotes a group of individuals who live together during important phases of their lifetime and are bound to each other by biological and/or social and psychological relationships (Avasthi, 2010). Being a complete entity, the family is considered as the main provider of care of an in-need member (Foster et al., 2012; Mcneil, 2012). This significant responsibility, however, results in a substantial level of stress and burden in caregiving especially in caring for a member with mental illness (Rose et al., 2004). Thus, the focus of care should not be solely centered on the illmember but should include the entire family. This care is termed as family centeredness.

Although family centeredness would seem to be focused on the nursing care of children (Hutchfield, 1999), its practice suggests a global concept of nursing care that embraces the whole family, with a multidimensional approach to care aimed at promoting well-being of the entire family throughout the entire course of the illness (Whittaker, 2017). Family centeredness can be applied to various levels of health care and in all branches of nursing - including mental health.

While family centeredness had been extensively explored in pediatric settings, there has been minimal insight done understanding this concept in mental health. Family stigma and caregiver burden in mental illness - terms all related to family centeredness are well-understood. However, the term's definition in the field of mental health remains vague, even though several studies have examined family experiences amidst mental illness. For a precise description of the term, this paper defined family centeredness in mental health using Walker and Avant's concept analysis method. The results of this analysis will enhance understanding of the concept and its theoretical and practical implications in the field of mental health care.

\section{Methods}

\section{Study Design}

Concept analysis is a process for deriving accurate theoretical and operational definitions of certain words, terms, or symbols by clarifying their fundamental properties (Park \& Park, 2014). For Walker and Avant (1994), "Concept analysis is a concept development, a process of determining the likeness and unlikeness between concepts and its basic purpose is to distinguish between the defining attributes and the irrelevant attributes" (p.38). As family centeredness in a mental health field is still an ambiguous concept, the strength of the method of Walker and Avant in providing a structural guideline seemed the most appropriate approach. 
Walker and Avant's method elucidates the concept by providing the definition, attributes, antecedents, consequences and empirical referents through the following steps: 1) select a concept; 2) determine the aims/purposes of analysis; 3 ) identify all uses of the concept that you can discover; 4) determine the defining attributes; 5) identify a model case; 6 ) identify borderline, related, contrary, invented and illegitimate cases; 7) identify antecedents and consequences, and; 8) define empirical referents.

\section{Data Gathering}

Given the aim of defining the concept of family centeredness in mental health, a systematic literature review was conducted. To be included in the present analysis, studies have to be papers in journals, dissertations, unpublished studies, experience reports, and theses; exploring issues and concerns of families with the mentally ill member. It should be written in English, published or written in the year 2000.

With the keywords "family", "mental health", "mental illness", "mental health care issues", "family-centered care and family-centered care in mental health, the EBSCOHost online search platform together with CINAHL, PubMed, and ProQuest databases were used. Additional literature was obtained through Google Search Engines and Google Scholar. The author also conducted a hand search in selected local libraries to determine some other unpublished works related to the topic of interest. The search and selection of articles were solely done by the researcher. Specific procedures for data collection are illustrated in Figure 1.

The initial search with the general keyword of family-centered care yielded 707 studies. Focusing on family-centered care in mental health, the volume was reduced to 266 studies. After further screening, removal of duplicates, and eligibility assessment, there remained 20 articles for analysis (Figure 1).

Overall, the review found eight discussion papers, four qualitative studies, three mixed methods, three literature reviews, and one master's Thesis. The papers were synthesized using a table indicating the name of authors, methodology, definition, attributes, antecedents, and consequences (Table 1). 


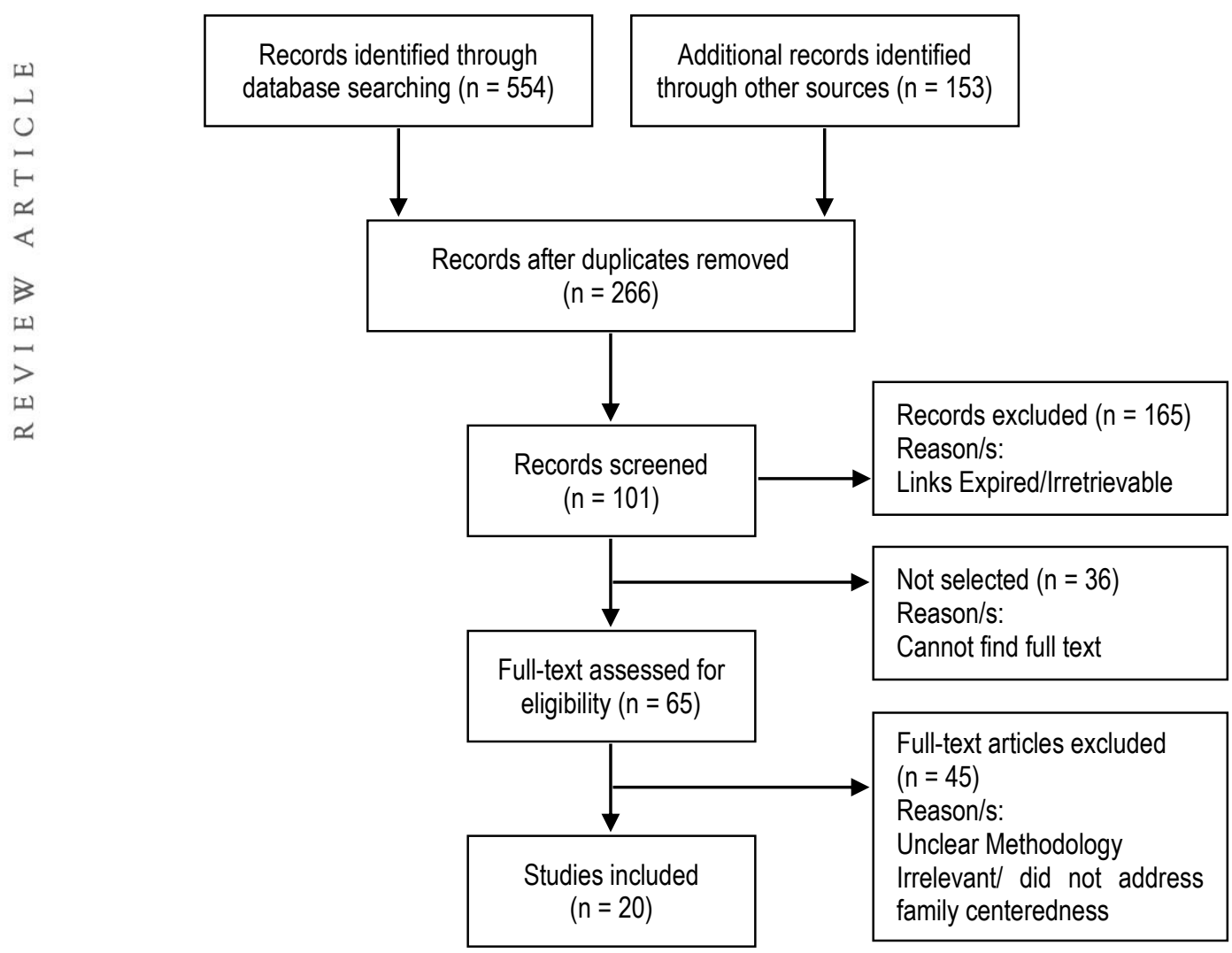

Figure. 1. Flow Diagram of the Article Selection Process

\section{Results}

\section{Definition and use of the concept}

In defining and determining the use of a concept, Walker and Avant (2005) recommended using dictionaries, thesauruses, and any other possible literature (Park \& Park, 2014). However, the concrete word "family centeredness" could not be found. Instead, the concept has been defined under the guise of different labels, including family-centered care, family-centered practice, and familycentered approach. client-centered therapy, patient-centered care, and relationship-centered care (Parrish et al., 2008).

The term family-centered care initially emerged in the maternity nursing literature in the 1970s (Dokken and Ahmann, 2007; as cited in Goldfarb et.al., 2010 p.92). Also, it was first defined in 1987 as part of former Surgeon General C. Everett Koop's initiative for family-focused, communitybased, coordinated care for children with special health care needs and their families (Brewer et.al., 1989; as cited in Goldfarb et al., 2010 p.92). Originated decades ago with the thrust of delivering the 
best care for sick minors, family-centered care has resulted in innovation in health care practice that resulted in the betterment of the care of hospitalized children (Jolley \& Shields, 2009).

Child Welfare Information Gateway (n.d.) termed family centeredness as Family-centered practice, a way of working with families, both formally and informally, across service systems to enhance their capacity to care for and protect their children. Raising Children.net.au (n.d.), an Australian Parenting website named it Family-centered approach, is defined as a way of working in partnership with families to help them make their own decisions in creating the best environment for children's health, development, and well-being.

From the children-centered approach, family centeredness' definition evolved. Recently, the practice redefined relationships in health care by emphasizing collaborating with people of all ages, at all levels of care, and in all health care settings (Family-centered care, n.d.). In the definition of the Institute for Patient and Family-Centered Care (n.d.), the concept was described as an approach to the planning, delivery, and evaluation of health care that is grounded in mutually beneficial partnerships among health care professionals, patients, and families.

The Medical Dictionary for the Health Professions and Nursing (n.d.) correspondingly labeled the concept as Family-centered care and defined as the application of services, therapies, and interventions that are based on the concerns and priorities of the family and not primarily on establishing the diagnosis. Similarly, the Medical Dictionary (n.d.) defined Family-centered care as the integration and collaboration of family members in the patient care team, especially in the care of infants, children, or adults with complex or continuing health care needs.

In the review of the literature, several studies were found describing family centeredness using a different terminology but similarly suggests a global concept of nursing care that embraces the whole family. Foster et al. (2012, p.7) termed it as family-focused care, a method of care delivery that respects and recognizes the pivotal role of the family, considers their uniqueness, and views them as a complete entity. Caqueo-Urizar et al. (2015) referred to it as family intervention, a collaborative relationship between the family and the treatment team to help patients make progress towards recovery. A family-centered approach is another term referring to family centeredness, which defines it as engaging families, providing education and attending to their needs (Heru, 2015); while McGavin (2013) referred to it as family-focused practice, an approach that emphasizes the family as the unit of attention, as opposed to working with an individual alone ( as cited in Grant \& Reupert, 2016).

Family centeredness was indeed being described and defined using different terminologies. The common theme that existed within these labels is that successful caregiving requires not only accurately diagnosing disease but also valuing the importance of human interactions in health care experiences and the legitimacy of the patient's (and parents') beliefs and practices (Parrish et al., 2008). Regardless of the term, they share the same principle: Family-centered care practice 
acknowledges the patient and family as the experts on themselves, involves families as collaborative partners in all aspects of services and decisions about care through mutually beneficial partnerships among health care providers, patients, and families; to help patients make progress towards recovery (Wong, 2014; Wong et al., 2016; Williams, 2014; Caqueo-Urizar et al., 2015).

\section{Defining Attributes of the Concept}

Walker and Avant (2005) state that the defining attributes are 'characteristics of the concept that appear over and over again (cited in Easley, 2007). Upon reviewing the relevant literature, noting and summarizing the characteristics that repeatedly appear, the defining attributes of family centeredness include:

a) A mutual, collaborative partnership between the patient, family and health care providers based on knowledge exchange, open communication and cooperation wherein families are not called or treated as dependent clients, but viewed as equals, as citizens with whom they work in partnership (Bamm, 2008; Goldfarb et al., 2010; McNeil, 2012; Wong et al., 2014, 2016; Grant \& Reupert, 2016; Foster et al., 2012, 2018, Ahmann \& Johnson, 2000; Park et al., 2018; Caqueo-Urizar et al., 2015)

b) A supportive, professional bond among health care providers, patient and family characterized by empathy, understanding, respect, and empowerment; with the patient as the center of care and families are supported in their natural caregiving role (Foster et al., 2012, 2018; Avasthi, 2010; McNeil, 2012; Ahmann \& Johnson, 2000; Heru, 2015; Hodgetts et al., 2013; Chien et al., 2013; Chadda, 2014; Bamm, 2008; Wong et al, 2016; Godfarb et al., 2010)

c) Individualized Care wherein the process is defined by the family is supported, enabling the opportunity to choose, control over decisions and empowerment (Foster et al., 2012; Avashti, 2010; Park et al., 2018; Bamm 2008; Goldfarb et al., 2010; Chadda, 2014; Williams, 2014).

\section{Collaborative relationship}

According to the Center for Addiction and Mental Health (CAMH, 2004), collaboration requires a shift in organizational practices and in the attitudes and behaviors of individual providers from a model in which professionals are seen as the only people in possession of expert knowledge to a model that is based on knowledge exchange and partnerships (as cited in McNeil, 2012).

World Health Organization (WHO, 2018) defined the collaborative relationship as a partnership between two or more parties and is based on trust, equality, and mutual understanding for the achievement of the specific goal. Family centeredness is a mutual, collaborative partnership 
between the patient, family, and health care providers.

Working with families of mentally-ill appears to be one of the most effective ways of delivering the community-based intervention to these patients (Chien et al., 2013), and with proven efficacy in reducing the negative impact of psychosis in caregivers, reduce negative attitudes and increase caregiver's willingness to provide care to their ill-member (Chadda, 2014). In family centeredness, families are not called or treated as dependent clients, but viewed as equals, as citizens with whom they collaborate (Bamm, 2008). In fostering collaborative partnerships with families, there is the provision of quality mental health information, education, and support, resulting in better continuity of care in all levels of health care delivery system and better relationships for everyone involved (Ahmann \& Johnson, 2000; Grant \& Reupert, 2016; Foster et al., 2012, 2018; Goldfarb et al., 2010; McNeil, 2012; Park et al., 2018; Wong et al., 2014, 2016).

\section{Supportive, Professional Bond}

Family centeredness is a mutual relationship between the patient, family, and health care provider anchored on empathy and understanding (Avasthi, 2010). Families are recognized in their contribution to care, supported in their natural caregiving roles, and focusing on their strengths (Avasthi, 2010; Foster et al., 2012). It is a professional engagement, thus the mental health care providers still exercise their capability and expertise in their field. But with the main goal of giving support, the mental health care providers need to extend their attention beyond giving information. The services should be anchored more on taking timely care of the needs of the caregivers, helping them to improve and maintain their well-being so that they can take better care of their loved ones (Chadda, 2014; Chien et al., 2013).

\section{Individualized Care}

As each individual is unique, the care provided should always be individualized. Family centeredness employs dignity and respect, with the consent and choice of the consumer taken into consideration (Ahmann \& Johnson, 2000; Foster et al., 2012). Since families are constant in the patients' life and best suited to determine the patients' needs, they are given choice and control over treatment decisions (Hodgetts et al., 2013).

Also, health care providers must recognize the distinct characteristics of each family. Although everyone needs help, it should be understood that help may be given differently, in a different frequency, in a different approach (Goldfarb et al., 2010). In considering the individualism of each family, there will be a chance for making a better choice of treatment, informed decision making and empowerment (Bamm, 2008; Hodgetts. et al., 2013; Park et al., 2018). Indeed, family centeredness is a process whereby help is defined by the family that is being supported (Goldfarb et al., 2010). 


\section{Case Studies}

To further expand the concept of family centeredness, four categories of case studies are provided. The concept analysis method described by Walker and Avant (2005) uses case studies to clarify the concept and its attributes (Park \& Park, 2014).

While cases may be invented or found in the literature, those presented here were taken from actual examples of the researcher's experience working with mentally-ill patients and their families. Descriptions used to identify each case are fictitious and are not based on the participant's actual names. The model case demonstrates all of the defining attributes of the concept. A borderline case is a case that contains most, but not all of the defining attributes. A related case is related to the concept but does not contain the clinical attributes; and the final contrary case is a clear example of what the concept is not (Walker \& Avant, 2005 as cited in Brush, 2011).

\section{Model Case}

Alvin is a 50-year old retired seaman. Being the eldest in the family, he became the father to his five siblings when their father died. His work as a seafarer enabled him to send all of them to schools and became professionals, and at the same time supporting the need of his widowed mother. Because of his devotion to family, he remained single until his retirement.

Years after he stopped working, his family noticed a change in his character. He became suspicious, aloof, always agitated, and had outbursts of anger. When his suspiciousness worsened to the point of becoming delusional, his family sought medical help. Rey was diagnosed to have Schizophrenia, paranoid type; and was admitted for treatment in a mental health facility. As a protocol, the institution assigned a case manager who will personally manage his situation.

His widowed mother, together with his brothers and sisters, was too disturbed and disheartened with what happened. During their first family therapy session with the case manager, they expressed their anxiety, asked information about the illness, and how will they be able to help Rey. Through a series of scheduled family therapy sessions, they were given psychoeducation, an intervention teaching the family about an illness to change any negative (and possibly false) ideas that family members may have about the illness. They were made to understand what is Schizophrenia and how to manage it. The sessions also include identifying each family member's strengths and using these to solve and manage their problems. Group therapy with other families having similar burdens was also done. During these sessions, the case manager gave ample time for each family member to comprehend the situation and verbalize their readiness to participate in the care. Eventually, every member of the family eagerly complied and attended the meetings regularly. These interventions increased their knowledge of the illness and strengthened their coping skills as they wait for Rey's recovery. 
Similarly, Rey was treated in the institution through medications and psychoeducation. Slowly, his symptoms lessened and began to understand his condition. Through the guidance of the case managers, he was able to accept his illness and learned skills on how to cope with it. It was difficult for Rey but the case manager and the other health care providers helped him in his recovery.

By the time that Rey was discharged, his family was ready and eager to welcome him. $\mathrm{He}$ stayed in their ancestral home together with his mother and the youngest brother who is still single. The siblings who are not staying with him tried their best to communicate with Rey through the phone. Every Sunday, the entire family would gather together for prayer time and have lunch. The other siblings also brought their family to associate with Rey and make him feel welcome. Since Rey is already retired, every sibling contributed to the continuance of his treatment. The first few years after the initial attack was difficult. Rey experienced a minor relapse which results in conflict with the other members. But the family was able to manage it through cooperation, understanding, and patience, with the continuous guidance of the case manager.

At present, Rey is helping his youngest brother in their delivery business, and he constantly had his follow-up check-ups. His case manager is also continuously monitoring his condition through collaborating with the family, his psychiatrists, and others involved in his care.

This model case study fully demonstrates all attributes of family centeredness, collaborative partnership, supportive relationship, and individualized care. Here, the need for the whole family was met, not only the patient. Every member was made to understand the illness, recognized their struggle, and strengthened their individual's capability needed to manage the present stressful situation that resulted in empowerment and improved quality of life.

\section{Borderline Case}

Jeric, 23 y.o. was brought to the mental health facility by his sister. He was reported to be violent and destructive with active visual and auditory hallucinations. During the admission, the sister willingly provided all the necessary information and had given consent for admission. During hospitalization that lasted for almost a year, Jeric had occasional visits from his family. In those brief visits, the hospital staff conducted conferences/meetings to give insights on Jeric's diagnosis and progress. The hospital staff requested a more frequent visit and specific time for psychoeducation, but the family said that "they were too busy and will just pay a visit if they have time."

After one year, Jeric was discharged in stable condition. His sister fetches him, and the hospital staff gave instructions regarding medications, follow-up checkups, and how to managed Jeric at home. They were even allowed to use the ambulance in going home, assisted by the social worker, for further assessment of the home environment. However, after three days, Jeric was brought back by a family member to the hospital. He had a relapse. It seems that his family is not ready to live with him in his present condition. Upon readmission, his verbalizations in dialect are: "Diri na lang ko kay 
tawhay." (I would rather stay here, at least I have peace of mind.)

Based on the case, there is an effort to implement family-centered care. The health care providers collaborated with and extended support to the family by involving them in the decisionmaking process, giving information about the patient's condition and progress, and assisting in discharge as well as evaluating the home environment. However, because the family can only have brief, occasional visits to Jeric, there was no in-depth engagement between the family and the health care provider. Family involvement needs time and effort exerted by both parties. In this case, there is an effort for collaboration and support, but the family is not yet ready to integrate the care of Jeric into their system. Managing people with a mental health condition is difficult, especially if the family is capable of handling it. Jeric might be ready to go back, but his family is not, and that stressful situation probably triggered the relapse.

\section{Related Case}

Juan is a 67-year-old male, a patient of a private mental health facility in Davao City. He is a member of a well-off family in the city but unfortunately succumbed to Schizophrenia at the early age of 21 . He was brought to the facility and had remained there since then because family members are not willing to take care of him. According to them, they are "afraid, incapable, and had their concerns to attend to." They believed that keeping Tomasito inside the facility is best for everyone. They just requested that they will be kept informed of the condition of Tomasito, and only communicates with the hospital administration to settle their financial obligations. They considered themselves lucky for finding an institution that can fully attend to Tomasito's needs so that they can also "carry on with their normal life". To date, Tomasito is a permanent resident of the facility. His immediate needs are provided (food, medicine, clothing) since the family is financially capable of sustaining his hospitalization; but is seldom visited by his kin.

This is an example of a related case. The needs of the entire family are being met, as the patient is well-taken cared of by the health care providers; and the family members were able to live a normal life. However, the clinical attributes are not present, as there is no collaborative and supportive partnership between the health care provider, patient, and family.

\section{Contrary Case}

Maria is a 35 year old female suffering from psychosis for almost three years. She is married with three children. Maria exhibits severe signs and symptoms that disrupt their community, and she was rumored as being 'possessed by demons'. Because the family is living in poverty and lacks intellect in understanding Maria's condition or how to take care of her, the husband decided to hide her. He left his children to the care of his parents, made a simple dwelling on the mountains, away from people. To be sure that Maria will not be able to escape, he made a wooden cage and kept her inside. 
Maria is still living inside the cage until now, slowly deteriorating. His husband is willingly taking care of her, although the toil of caregiving is breaking him apart. The children are growing without their parents, but the husband believed that this is the only best thing that he can do for his wife and the children.

This final case is an example of a contrary case, as the family had no awareness about the illness and it's proper management, did not even seek any professional help, and still struggling until at present.

\section{Antecedents of Family Centeredness}

Walker and Avant (2005) defined antecedents as "those events or incidents that must occur before the occurrence of the concept (as cited in Park \& Park, 2014). Regarding family centeredness, these include:

\section{Presence of Mental IIIness in a Family Member}

Severe mental illness is stressful, not only for the individual but also for the entire family as this ill individuals live with their family rather than in mental health institutions and eventually becomes an increasing family concern.

Families of people with severe mental illness have significant responsibility for providing support and care for their relatives over extended periods, in many cases years and decades (Rose et al., 2004). Often represented as the primary source of support, family members are referred to as critical resources of care, central support system, main carers for patients and primary caregivers (Avashti, 2010; Caqueo-Urizar et al., 2015, Chadda, 2014; Chien et al., 2013). According to studies, social support networks among those living with serious mental illness are typically smaller and more restricted, and primarily consist of kin as compared with the general population (Froland et al., 2000; Perese \& Wolf 2005; Philips 1981; as cited in Duca, 2010). This small, kin-dominated network plays multiple roles in care for the psychiatric patient, including day-to-day care, supervising medications and check-ups, taking care of financial needs, and bear with the behavioral disturbances of the illmember (Chadda, 2014; Duca, 2010). Thus, in the health care field, the family represents one of the most valuable sources of support, recovery, and essential insights on the behavior and coping strategies of the individual (Bamm, 2008).

\section{Experience of Burden}

Severe illness or injury brings with it an inevitable distortion of family dynamics and equilibrium (Bamm, 2008). In mental illness, many of the families experience a substantial level of stress and burden that adversely affect the health of the individual members and the entire family unit 
(Doornbos, 2002; as cited in Rose, et al. 2004). As the support systems of families living with the mentally-ill member are limited, the reliance on this small, restricted network increases interpersonal stress and lead to greater emotional disturbance in family interactions (Vaugn \& Leff, 1981; as cited in Duca 2010).

The impact of mental illness on the caregivers has been termed as the burden of care. According to Platt (1985), the burden of care is the presence of problems, difficulties, or adverse events that affect the lives of the psychiatric patient's significant others (cited in Avashti, 2010, p.116). These include disruptions in social functioning, economic burden, feeling of loss, shame, guilt, anger and embarrassment that results in much distress, suffering and reduced quality of life (Avasthi, 2010; Caqueo-Urizar et al., 2015; Chadda, 2014; Chien et al., 2013; Duca, 2010; Foster et al., 2012, 2018; Heru, 2015; Leonard et al., 2018; McNeil, 2012; Rose et al., 2004).

\section{Acknowledgement of Responsibility}

Although addressing mental health problems is one of the functions of the government, the burden of care falls into family members. Being the primary caregiver of persons with mental illness, the family attends to the needs of the ill-member from onset, admission to discharge. The family caregiver plays multiple roles in care of persons with mental illness, including day-to-day care, supervising medications, taking the patient to the hospital and looking after the financial needs (Chadda, 2014; Caqueo-Urizar, et al. 2015). Common identified reason of this family provision of care to an ill-member is the paucity of trained mental health professionals required to cater to the vast majority of the population (Avasthi, 2010; Caqueo-Urizar, et al. 2015). However, aside from the mere responsibility of providing the needed health assistance of the ill-member, the value of love and concern for a dear one in adversity posits a greater reason for the care given. Being considered as a single complete entity, families are the primary carers of their ill-member. (Avasthi, 2010, CaqueoUrizar, et al. 2015, Chadda, 2014; Chien et.al. 2013; Foster, et.al. 2012; McNeil, 2012; Rose, et al, 2004).

\section{Constant Presence}

Family is the central to and/or the constant in the life of every member, the primary source of strength and support and best suited to determine the needs of each one (Bamm, 2008; Hodgetts et.al. 2013). Regardless of the type of disorder, it is the family caregivers who takes care of the dayto-day needs of patients. In mental illness, this needs includes monitoring of the mental state, identify the early signs of illness, relapse and deterioration, supervise treatment and access to services, and provision of emotional support (Chadda, 2014, Caqueo-Urizar, et al. 2015). Assuming the caring role for mentally ill individual is a constant responsibility. Taking on this caring role is at an important cost for the caregiver, who loses a series of opportunities for his personal and working growth (CaqueoUrizar, et al. 2015). Caregivers have to curtail on their leisure and social activities, and sometimes have to leave their jobs (Chadda, 2014) to continuously provide care. However, families still prefer 
to be meaningfully involved in all aspects of care of their ill-member (Avasthi, 2010). Despite the odds of experiencing confusion, frustration, fear, sadness, grief, anger, resentment and guilt, families still holds on to hope, caring, compassion, sympathy and love (Chadda, 2014).

\section{Consequents of Family Centeredness}

Walker and Avant (2005) defined the consequences of the concept as the outcomes or results of the occurrence of the concept (as cited in Park \& Park, 2014), and can often stimulate new ideas or avenues for research (Brush et al., 2011).

In this concept analysis, identified consequences are reduced burden of care to families (Foster et al., 2012; Caqueo-Urizar et al., 2015; Hodgetts et al., 2013; Duca, 2010; Chien et al., 2013; Foster et al., 2018; and Leonard et al., 2018); improved patient outcomes that include reducing relapse rate, hospital admissions and increased medication compliance (Chadda, 2014; Chien et al., 2013; Duca, 2010; Foster et al., 2012, 2018; Heru, 2015; Hodgetts et al., 2013; Park et al., 2018; and Williams, 2014); and better quality of life that includes improved social functioning, empowerment and resilience to both caregiver and patient (Ahmann \& Johnson, 2000; Avashti, 2010; Bamm, 2008; Caqueo-Urizar et al., 2015; Chadda 2014; Chien et al., 2013; Foster et al., 2018 ; Hodgetts et al., 2013; Park et al., 2018; Williams, 2014).

Family centeredness also resulted in a paradigm shift for healthcare provider's practice from a professional-centered model in which professionals are regarded as the experts to a familycentered model in which families and professionals share power and control and work collaboratively (Espe-Sherwindt, 2008; Mohr, 2000; cited in Wong et al., 2016). As a consequence, there is improved quality of care characterized by increased confidence in work, increased job satisfaction, improved experience in health care delivery and reduced stress and burnout by generating a right working environment for practitioners (Park et al., 2018; Williams, 2014; Wong, 2014; Wong et al., 2016).

ANTECEDENTS

\begin{tabular}{|l|l|l|l|}
\hline $\begin{array}{l}\text { PRESENCE of MENTAL } \\
\text { ILLNESS in a FAMILY } \\
\text { MEMBER }\end{array}$ & $\begin{array}{l}\text { REDUCED BURDEN of } \\
\text { CARE } \\
\text { EXPERIENCE of BURDEN } \\
\text { MUTUAL COLLABORATIVE } \\
\text { ACKNOWLEDGEMENT of } \\
\text { RESPONSIBILITY } \\
\text { CONSTANT PRESENCE }\end{array}$ \\
IMPROVED PATIENT \\
OUTCOMES \\
SUPPORTIVE \\
PROFESSIONAL BOND \\
INDIVIDUALIZED CARE \\
BETTER QUALITY OF LIFE \\
IMPROVED QUALITY OF \\
CARE (for health \\
professionals)
\end{tabular}

Figure 2. Conceptual Model of Family Centeredness 


\section{Empirical Referents}

Empirical referents are classes or categories of actual phenomena that by their existence or presence demonstrate the occurrence of the concept itself (Walker \& Avant, 2005). Once identified, the empirical referents are useful regarding developing the instrument since they are developed based on the theoretical analysis of the concept (Walker \& Avant, 2005).

So far, there is no known tool specifically measuring family centeredness in mental health. The majority of the assessment tools are on pediatric care, focusing on helping families of children with special needs. Some of those are Self-Assessment Family Tool (Engaging Patients \& Families, 2020), Perceptions of Family-Centered Care: Parent, Perceptions of Family-Centered Care: Staff and Parental Stress Care: Neonatal Care Unit (Balbino et al., 2016). Standardized Surveys assessing the experiences of consumers receiving different types of health care in hospitals, nursing homes, hospice, and end of life are also existing (Berselli et al., 2018).

For this research, the defining attributes of family centeredness are abstract and hard to measure. The degree of collaboration, level of support, and promotion of individualized care is better assed through qualitative studies because it is more on the in-depth experiences of the persons involved, thus very difficult to quantify. More so, it is also appropriate to include the identified antecedents (Family being the main provider of care and Caregiver Burden) and consequents (reduced burden of care, improve patient outcomes, the better quality of life, and improve quality of care) to qualitatively measure family centeredness.

\section{Discussion}

Family denotes a group of individuals who live together during important phases of their lifetime and are bound to each other by biological and/or social and psychological relationships (Avasthi, 2010). Being a complete entity, the family is considered as the main provider of care of an in-need member (Foster et al., 2012, Mcneil, 2012). This significant responsibility, however, results in a substantial level of stress and burden in caregiving especially in caring for a member with mental illness (Rose et.al. 2004). Thus, the focus of care should not be solely centered on the ill-member but should include the entire family.

In this study, three attributes of family-centered care were explored: (a) Family Centeredness is a mutual, collaborative partnership between the patient, family and health care providers based on knowledge exchange, open communication and cooperation wherein families are not called or treated as dependent clients, but viewed as equals, as citizens with whom they work in partnership; (b) it is a supportive, professional bond among health care providers, patient, and family characterized by empathy, understanding, respect, and empowerment; with the patient as the center of care and families are supported in their natural caregiving role; and (c) Individualized care wherein 
the process is defined by the family is supported, enabling the opportunity to choose, control over decisions and empowerment.

Finally, the consequences of family centeredness were identified. For the family, employing family centeredness in the care of mentally-ill individuals results in the reduced burden of care, improved patient outcomes, better quality of life. It also results in improved quality of care for health professionals.

Understanding family centeredness is essential in the field of mental health care. Indeed, the result of this analysis has several implications in nursing practice. First, as the ill-member reintegrates into the community after institutional treatment, the family will be the main support system and has to be strengthened and supported. They will be the health care provider's natural allies in caring; monitoring medication adherence, observing for side effects, keeping close attention to relapse, help keep appointments, promote a caring environment, and provide emotional support. Indeed, working with families appears to be one of the most effective ways of delivering the community-based intervention to mental patients (Chien et al., 2013). Thus, the health care providers should understand that the family members should be helped, supported, and be included in the team so that they care for their loved ones; they will also maintain their health and well-being.

Also, health care providers must realize the importance of family centeredness because of its difference from traditional caring practices. In family centeredness, there is a shift from the individually focused medical model to the systemic and strength-based perspective; from thinking of families as part of the problem to seeing them as part of the solution; and from a professional-centered model in which professionals are regarded as the experts to a family-centered model in which families and professionals work collaboratively (Wong, 2014). Family centeredness is a focus away from health professions and towards the empowerment of individuals and family as active collaborators in decision-making (Williams, 2014). The researcher hopes that this study will cause health care providers to reexamine their perceptions and stereotypes (if there are any) to the patient and their families to promote a better therapeutic relationship.

In many western countries, family centeredness has been recognized as one of the best practice approaches for adult mental health care practice (Carr, 2009 as cited in Wong et al., 2016). However, in a nonwestern world, nurturing a new practice approach presents an enormous challenge (Wong et al., 2016). In Hongkong, a family-centered approach to adult mental health care is almost non-existent (Wong \& Ma, 2013; as cited in Wong et al., 2016). In India, where there are a limited number of healthcare workers, importance is being given to the ill individual - ignoring the caregivers (Avasthi, 2010). Many factors result in poor or even absent implementation of family centeredness in mental health in the third world and non-western countries. However, the time has come to recognize the family members' contribution to the treatment and rehabilitation of mentally ill patients. Successful implementation of family-centered practice requires a coordinated effort across all levels of the mental health service delivery system, including not only the service users and their families but also mental 
health social workers, administrators, and policymakers (Wong et al., 2016).

\section{Limitations}

There are several limitations to this paper. First, the studies were screened and reviewed by only the author. Therefore, there might be some bias in the study selection and the information that contributed to defining the attributes, antecedents, and consequences. Second, cultural factors are important to the concept of family. However, such cultural aspects were not considered. Finally, inability to access full text articles was also considered as a limitation, for the supposed inclusion of those articles would have broadened and strengthened the result of the study.

\section{Conclusion}

Health care providers, including nurses, meet numerous patients daily and tend to focus only on patients' medical conditions. However, as shown in the result of this analysis, mental illness affects the entire family and should be cared for as a whole entity. Family members are the primary caregivers of persons with mental illness, and this key support system cannot be ignored or taken for granted. The defining attributes of this concept analysis were found to be the key in identifying the essential role of the family as partners in the provision of health care and at the same time recognizing their need to be cared. Family centeredness is indeed an approach characterized by active collaboration with families, building a therapeutic relationship based on understanding, support and empathy; and provision of needs in an individualized approach and frequency, recognizing the uniqueness of every family member involved.

May the results of this analysis of family centeredness will not only extend the body of knowledge on nursing theory and practice but also pave the way for health care providers to view and care for their patients more deeply and thoughtfully, beyond just focusing on their medical conditions, but with the inclusion of the whole family in the caring process.

\section{Directions for Future Research}

This research had shown the benefit of family centeredness in mental health care. Unfortunately, its implementation specifically in non-western and third world countries is not as robust as of the west. Thus, future researches should focus on the assessment of a focused family approach in countries wherein it is almost non-existent. Doing so could enlighten reasons why family centeredness is not a prioritized intervention in mental health care, and for those reasons and barriers to be addressed appropriately.

Moreover, this analysis can promote communication between nursing researchers for a 
better understanding of the concept which can lead to the development of related theories, models, and measurement tools in nursing. Lastly, the result of the study can contribute to more family-related research; as a family is a major component in the patient's recovery.

\section{Conflict of Interest}

The author has no conflict of interest to disclose.

Table 1. Summary of Included Studies

\begin{tabular}{|c|c|c|c|c|c|}
\hline & Methodology & Definition & Attributes & Antecedents & Consequences \\
\hline $\begin{array}{l}\text { Foster et } \\
\text { al., } 2012\end{array}$ & $\begin{array}{l}\text { Literature Search/ } \\
\text { Discussion Paper }\end{array}$ & $\begin{array}{l}\text { Family } \\
\text { centeredness/family- } \\
\text { focused care is a } \\
\text { method of care } \\
\text { delivery that respects } \\
\text { and recognizes the } \\
\text { pivotal role of the } \\
\text { family }\end{array}$ & $\begin{array}{l}\text { Family } \\
\text { collaboration } \\
\text { Supporting } \\
\text { families in their } \\
\text { natural caregiving } \\
\text { roles }\end{array}$ & $\begin{array}{l}\text { The family is a } \\
\text { complete entity } \\
\text { Mental illness } \\
\text { causes } \\
\text { psychosocial and } \\
\text { mental health } \\
\text { problems to family }\end{array}$ & $\begin{array}{l}\text { Reduce the } \\
\text { burden of care } \\
\text { Strengthen } \\
\text { individual and } \\
\text { family resilience }\end{array}$ \\
\hline $\begin{array}{l}\text { Avasthi, } \\
2010\end{array}$ & $\begin{array}{l}\text { Literature Search/ } \\
\text { Discussion Paper }\end{array}$ & $\begin{array}{l}\text { Family } \\
\text { centeredness/Family- } \\
\text { based interventions } \\
\text { focus on the } \\
\text { strengths of } \\
\text { caregivers }\end{array}$ & $\begin{array}{l}\text { Building a } \\
\text { relationship with } \\
\text { caregivers based } \\
\text { on understanding } \\
\text { and empathy, } \\
\text { focusing on their } \\
\text { strengths }\end{array}$ & $\begin{array}{l}\text { Family as the } \\
\text { primary care } \\
\text { provider } \\
\text { Interconnectedness } \\
\text { Burden of care } \\
\text { Diminished self- } \\
\text { worth }\end{array}$ & $\begin{array}{l}\text { Family } \\
\text { centeredness } \\
\text { contributes to a } \\
\text { better outcome } \\
\text { and improved } \\
\text { quality of life } \\
\text { Reduces relapse }\end{array}$ \\
\hline $\begin{array}{l}\text { Caqueo- } \\
\text { Urizar, et } \\
\text { al., } 2015\end{array}$ & $\begin{array}{l}\text { Literature Search/ } \\
\text { Discussion Paper }\end{array}$ & $\begin{array}{l}\text { Family } \\
\text { centeredness/family } \\
\text { interventions is a } \\
\text { collaborative } \\
\text { relationship between } \\
\text { the family and the } \\
\text { treatment team to } \\
\text { help patients make } \\
\text { progress towards } \\
\text { recovery }\end{array}$ & $\begin{array}{l}\text { Collaborative } \\
\text { relationship }\end{array}$ & $\begin{array}{l}\text { The family is the } \\
\text { main support } \\
\text { system } \\
\text { Burden of Care } \\
\text { Reduce caregivers } \\
\text { quality of life }\end{array}$ & $\begin{array}{l}\text { Positive impact on } \\
\text { patient's recovery } \\
\text { and improvement } \\
\text { of social } \\
\text { functioning that } \\
\text { includes } \\
\text { caregivers } \\
\text { Reduce levels of } \\
\text { burden } \\
\text { Increase } \\
\text { caregivers } \\
\text { perception of self- } \\
\text { efficacy and social } \\
\text { support, and } \\
\text { levels of } \\
\text { satisfaction }\end{array}$ \\
\hline $\begin{array}{l}\text { McNeil, } \\
2012\end{array}$ & $\begin{array}{l}\text { Qualitative, } \\
\text { exploratory } \\
\text { research }\end{array}$ & $\begin{array}{l}\text { Family } \\
\text { centeredness/family- } \\
\text { centered care refers } \\
\text { to welcoming and } \\
\text { respecting family } \\
\text { members as partners } \\
\text { in caregiving, } \\
\text { program planning, } \\
\text { and policymaking }\end{array}$ & $\begin{array}{l}\text { Fostering a } \\
\text { collaborative } \\
\text { partnership with } \\
\text { the family } \\
\text { Providing quality } \\
\text { mental health } \\
\text { information, } \\
\text { education, and } \\
\text { support Involving } \\
\text { families in } \\
\text { professional }\end{array}$ & $\begin{array}{l}\text { Families are } \\
\text { primary providers } \\
\text { of care } \\
\text { Families are } \\
\text { blamed for failing to } \\
\text { manage the } \\
\text { patient's deviant } \\
\text { behavior }\end{array}$ & $\begin{array}{l}\text { Improve patient } \\
\text { outcomes } \\
\text { Family members } \\
\text { feel involved, } \\
\text { informed and } \\
\text { supported }\end{array}$ \\
\hline
\end{tabular}




\begin{tabular}{lll}
\hline & Methodology & \multicolumn{1}{c}{ Definition } \\
\hline Rose et & $\begin{array}{l}\text { Qualitative, } \\
\text { exploratory } \\
\text { research }\end{array}$ & $\begin{array}{l}\text { Family } \\
\text { centeredness/family } \\
\text { care is a response to } \\
\text { the primary illness } \\
\text { education or support } \\
\text { for illness-related } \\
\text { stress }\end{array}$ \\
\end{tabular}

Ahmann \& Discussion Paper
Johnson,
2000

Heru, 2015 Discussion Paper

Hodgetts Mixed method et al., 2013 study

Park et al., Literature Review 2018
Family

centeredness/Familycentered care is an approach to the planning, delivery, and evaluation of health care that is grounded in mutually beneficial partnerships among health care providers, patients, and families.

\section{Family} centeredness/familycentered approach to care is about engaging families, providing education and attending to their needs

\section{Family}

centeredness/familycentered care is a broadly defined practice philosophy in which parents and service providers work in partnership, and supports and services coincide with changing needs and priorities of the family

\section{Family} centeredness/familycentered care requires mutual power-sharing relationships that are collaborative and include the "whole person orientation."

\section{Attributes Antecedents}

\section{Consequences}

training, research, and policymaking

The family have significant responsibility for providing care and support to their mentally ill relatives Families experience a substantial level of stress and burden in caregiving

Collaboration among patients, families and healthcare providers People are treated with dignity and respect Communication and sharing of unbiased information

Family inclusion

Caregiver Burden

Improve patient and caregiver outcome

Families are given choice and control over treatment decisions

The family are Increased parent constant in a child's satisfaction life and best suited to determine their Decreased parent stress child's needs
Enhance control and independence of families by building on their strengths outcomes

Collaborations among patient, family and healthcare providers

\author{
A positive \\ outcome, \\ improvement of \\ the quality of life \\ and empowerment \\ to patient and \\ family \\ Generates the \\ right working
}




\begin{tabular}{|c|c|c|c|c|c|}
\hline & Methodology & Definition & Attributes & Antecedents & Consequences \\
\hline & & & & & $\begin{array}{l}\text { environment for } \\
\text { practitioners }\end{array}$ \\
\hline $\begin{array}{l}\text { Duca, } \\
2010\end{array}$ & $\begin{array}{l}\text { Qualitative, } \\
\text { exploratory } \\
\text { research }\end{array}$ & $\begin{array}{l}\text { Family centeredness } \\
\text { is family involvement } \\
\text { in the treatment } \\
\text { approach }\end{array}$ & $\begin{array}{l}\text { Family } \\
\text { participation }\end{array}$ & $\begin{array}{l}\text { Restricted social } \\
\text { support } \\
\text { Caregiver burden } \\
\text { The family is the } \\
\text { significant source } \\
\text { of support of the ill } \\
\text { member }\end{array}$ & $\begin{array}{l}\text { The decreased } \\
\text { burden of care } \\
\text { Hasten recovery } \\
\text { process }\end{array}$ \\
\hline $\begin{array}{l}\text { Chien et } \\
\text { al., } 2013\end{array}$ & $\begin{array}{l}\text { Literature } \\
\text { Review/ } \\
\text { Discussion Paper }\end{array}$ & $\begin{array}{l}\text { Family } \\
\text { centeredness/family- } \\
\text { focused interventions } \\
\text { are interventions } \\
\text { directed to patient } \\
\text { and family members } \\
\text { focusing on the } \\
\text { family need and } \\
\text { aiming to reduce } \\
\text { patient relapse and } \\
\text { readmission }\end{array}$ & $\begin{array}{l}\text { A collaborative } \\
\text { relationship with } \\
\text { the family } \\
\text { Psychosocial } \\
\text { therapies } \\
\text { Spiritual therapy } \\
\text { Family education } \\
\text { Psychoeducation }\end{array}$ & $\begin{array}{l}\text { Family members } \\
\text { are primary carers } \\
\text { of patients in the } \\
\text { community } \\
\text { Caring has a } \\
\text { burdensome effect }\end{array}$ & $\begin{array}{l}\text { Improvement in } \\
\text { the mental status } \\
\text { and psychosocial } \\
\text { functioning of } \\
\text { patients } \\
\text { Reducing family } \\
\text { burden } \\
\text { Increase the } \\
\text { quality of life }\end{array}$ \\
\hline $\begin{array}{l}\text { Chadda, } \\
2014\end{array}$ & Discussion Paper & $\begin{array}{l}\text { Family } \\
\text { centeredness/family- } \\
\text { based interventions } \\
\text { mean the } \\
\text { involvement of } \\
\text { families in the care of } \\
\text { the mentally ill }\end{array}$ & $\begin{array}{l}\text { Psychoeducation } \\
\text { Proven efficacy in } \\
\text { reducing the } \\
\text { negative impact } \\
\text { of psychosis in } \\
\text { caregivers, } \\
\text { reduce negative } \\
\text { attitudes and } \\
\text { increase } \\
\text { caregiver's } \\
\text { willingness to } \\
\text { provide care to } \\
\text { their ill-member }\end{array}$ & $\begin{array}{l}\text { Family members } \\
\text { are the primary } \\
\text { caregivers of } \\
\text { persons with } \\
\text { mental illness } \\
\text { Family caregiver } \\
\text { experiences a } \\
\text { considerable } \\
\text { amount of stress } \\
\text { and burden }\end{array}$ & $\begin{array}{l}\text { Reduce relapse } \\
\text { rates } \\
\text { Reduce the } \\
\text { negative impact of } \\
\text { psychosis among } \\
\text { caregivers } \\
\text { Reduce negative } \\
\text { attitudes and } \\
\text { increasing the } \\
\text { willingness of } \\
\text { caregivers in } \\
\text { providing care for } \\
\text { the patient }\end{array}$ \\
\hline $\begin{array}{l}\text { Foster et } \\
\text { al., } 2018\end{array}$ & $\begin{array}{l}\text { Integrative } \\
\text { literature review }\end{array}$ & $\begin{array}{l}\text { Family } \\
\text { centeredness/family- } \\
\text { focused practice } \\
\text { refers to how mental } \\
\text { clinicians and mental } \\
\text { health services } \\
\text { respond to other } \\
\text { family members } \\
\text { when an adult or } \\
\text { child has the } \\
\text { identified health } \\
\text { problem }\end{array}$ & $\begin{array}{l}\text { "Whole of Family" } \\
\text { approach to care } \\
\text { Psychoeducation } \\
\text { Acknowledging } \\
\text { and responding } \\
\text { to families in their } \\
\text { caring role and } \\
\text { how they cope } \\
\text { Collaborative, } \\
\text { respectful, open } \\
\text { and honest } \\
\text { relationship } \\
\text { between the } \\
\text { professional } \\
\text { team, } \\
\text { consumer/patient, } \\
\text { and family }\end{array}$ & $\begin{array}{l}\text { All family members } \\
\text { are affected by } \\
\text { mental illness }\end{array}$ & $\begin{array}{l}\text { Improvement of } \\
\text { patient } \\
\text { Reduction in the } \\
\text { subjective burden } \\
\text { of care } \\
\text { Increased levels of } \\
\text { self-care and } \\
\text { emotional role } \\
\text { functioning among } \\
\text { caregivers }\end{array}$ \\
\hline $\begin{array}{l}\text { Bamm, } \\
2008\end{array}$ & $\begin{array}{l}\text { Literature } \\
\text { review/Discussion } \\
\text { Paper }\end{array}$ & $\begin{array}{l}\text { Family } \\
\text { centeredness/Family- } \\
\text { centered care is an } \\
\text { innovative approach } \\
\text { to the planning, } \\
\text { delivery, and } \\
\text { evaluation of health }\end{array}$ & $\begin{array}{l}\text { Promote family- } \\
\text { to-family and } \\
\text { community-based } \\
\text { systems of care } \\
\text { and mutual } \\
\text { support }\end{array}$ & $\begin{array}{l}\text { Client-centered } \\
\text { practice } \\
\text { Recognition of the } \\
\text { significance of } \\
\text { treating the patient } \\
\text { in the context of } \\
\text { family and the }\end{array}$ & $\begin{array}{l}\text { Mutual influence } \\
\text { on the treatment } \\
\text { process, family } \\
\text { dynamics and } \\
\text { individual function } \\
\text { and participation } \\
\text { in social life }\end{array}$ \\
\hline
\end{tabular}




\begin{tabular}{|c|c|c|c|c|c|}
\hline & Methodology & Definition & Attributes & Antecedents & Consequences \\
\hline & & $\begin{array}{l}\text { care that is grounded } \\
\text { in mutually beneficial } \\
\text { partnerships among } \\
\text { patients, families, } \\
\text { and providers. It } \\
\text { applies to patients of } \\
\text { all ages, and it may } \\
\text { be practiced in any } \\
\text { healthcare setting }\end{array}$ & $\begin{array}{l}\text { Promote } \\
\text { collaboration and } \\
\text { empowerment }\end{array}$ & $\begin{array}{l}\text { general perception } \\
\text { of the family as the } \\
\text { basic social unit - } \\
\text { the foremost } \\
\text { educator, } \\
\text { supporter, and } \\
\text { shaper of each } \\
\text { person } \\
\text { Family systems } \\
\text { theory }\end{array}$ & \\
\hline $\begin{array}{l}\text { Wong, } \\
2014\end{array}$ & Mixed-Method & $\begin{array}{l}\text { Family-centered care } \\
\text { practice } \\
\text { acknowledges the } \\
\text { patient and family as } \\
\text { the experts on } \\
\text { themselves and } \\
\text { involves families as } \\
\text { collaborative partners } \\
\text { in all aspects of } \\
\text { services and } \\
\text { decisions about care }\end{array}$ & $\begin{array}{l}\text { Collaborative } \\
\text { partnerships }\end{array}$ & & $\begin{array}{l}\text { Nurses were } \\
\text { energized in their } \\
\text { role by practicing } \\
\text { specialized clinical } \\
\text { skills such as } \\
\text { family-centered } \\
\text { practice }\end{array}$ \\
\hline $\begin{array}{l}\text { Wong et } \\
\text { al., } 2016\end{array}$ & Exploratory study & $\begin{array}{l}\text { Family-centered care } \\
\text { recognizes the } \\
\text { centrality of family in } \\
\text { the lives of } \\
\text { individuals, } \\
\text { acknowledges the } \\
\text { service users and } \\
\text { family as the experts } \\
\text { on themselves, and } \\
\text { involves clients and } \\
\text { families as } \\
\text { collaborators in all } \\
\text { systems providing } \\
\text { care }\end{array}$ & $\begin{array}{l}\text { Regard the family } \\
\text { as the basic unit } \\
\text { of care } \\
\text { Recognizing the } \\
\text { importance of } \\
\text { partnership } \\
\text { among providers, } \\
\text { clients, and family } \\
\text { members } \\
\text { Facilitating } \\
\text { professional } \\
\text { collaboration at } \\
\text { all levels of } \\
\text { healthcare } \\
\text { delivery }\end{array}$ & & $\begin{array}{l}\text { Challenging the } \\
\text { paradigm shift for } \\
\text { psychiatric social } \\
\text { workers }\end{array}$ \\
\hline $\begin{array}{l}\text { Leonard et } \\
\text { al., } 2018\end{array}$ & Literature review & $\begin{array}{l}\text { The family-focused } \\
\text { practice is an } \\
\text { umbrella term } \\
\text { encompassing a } \\
\text { continuum of family- } \\
\text { focused care } \\
\text { activities }\end{array}$ & $\begin{array}{l}\text { Whole family } \\
\text { approach }\end{array}$ & $\begin{array}{l}\text { Burden of care } \\
\text { Family as the unit } \\
\text { of care }\end{array}$ & $\begin{array}{l}\text { Reduces the } \\
\text { burden of care of } \\
\text { families } \\
\text { Provides a } \\
\text { preventive and } \\
\text { supportive } \\
\text { function for } \\
\text { children }\end{array}$ \\
\hline $\begin{array}{l}\text { Goldfarb } \\
\text { et al., } 2010\end{array}$ & Discussion paper & $\begin{array}{l}\text { Family-centered care } \\
\text { is a process whereby } \\
\text { help is defined by the } \\
\text { family that is being } \\
\text { supported }\end{array}$ & $\begin{array}{l}\text { Collaboration } \\
\text { between parents } \\
\text { and health care } \\
\text { providers }\end{array}$ & & \\
\hline $\begin{array}{l}\text { Grant \& } \\
\text { Rupert, } \\
2016\end{array}$ & Mixed method & $\begin{array}{l}\text { The family-focused } \\
\text { practice is an } \\
\text { approach that } \\
\text { emphasizes the } \\
\text { family as the unit of } \\
\text { attention, as } \\
\text { opposed to working }\end{array}$ & $\begin{array}{l}\text { Collaborating with } \\
\text { other services to } \\
\text { meet the needs } \\
\text { of families } \\
\text { Providing } \\
\text { information to the } \\
\text { family }\end{array}$ & & \\
\hline
\end{tabular}




\begin{tabular}{|c|c|c|c|c|c|}
\hline & Methodology & Definition & Attributes & Antecedents & Consequences \\
\hline & & $\begin{array}{l}\text { with an individual } \\
\text { alone }\end{array}$ & & & \\
\hline $\begin{array}{l}\text { Williams, } \\
2014\end{array}$ & Master's Thesis & $\begin{array}{l}\text { Family } \\
\text { centeredness/Family- } \\
\text { centered care is an } \\
\text { approach to the } \\
\text { planning, delivery, } \\
\text { and evaluation of } \\
\text { health care that is } \\
\text { grounded in mutually } \\
\text { beneficial } \\
\text { partnerships among } \\
\text { health care } \\
\text { providers, patients, } \\
\text { and families. }\end{array}$ & $\begin{array}{l}\text { Placing the } \\
\text { patient in the } \\
\text { center of care } \\
\text { Treating the } \\
\text { patient as a } \\
\text { whole, within the } \\
\text { community } \\
\text { Including the } \\
\text { patient as } \\
\text { identified by the } \\
\text { client } \\
\text { Inclusiveness } \\
\text { Compassion } \\
\text { Respect } \\
\text { Dignity }\end{array}$ & & $\begin{array}{l}\text { Reduce relapse } \\
\text { rate and hospital } \\
\text { admissions } \\
\text { Lower mortality } \\
\text { Increased } \\
\text { medication } \\
\text { compliance } \\
\text { Empowerment } \\
\text { Improved } \\
\text { experience in } \\
\text { health care } \\
\text { delivery of health } \\
\text { care workers }\end{array}$ \\
\hline
\end{tabular}

\section{References}

Ahmann, E. \& Johnson, B.H. (2000). Family-centered care: Facing the new millennium. Pediatric Nursing, 26, $1,87-90$.

Arksey, H. \& O'Malley, L. (2005). Scoping studies: Towards a methodological framework. International Journal of Social Research Methodology, 8(1), 19-32. https://doi.org/10.1080/1364557032000119616

$\mathrm{Au}, \mathrm{A}$. (2017). Redefining the Family in Mental Health: Understanding Norms and Improving Professional Practice. Mental Health in Family Medicine, 13, 566-569.

Avasthi, A. (2010). Preserve and Strengthen Family to promote mental health. Indian Journal of Psychiatry, 52(2), 113-26. https://doi.org/10.4103/0019-5545.64582

Balbino, F.S., Balierio, M.M. \& Mandetta, M.A. (2016). Measurement of Family-centered Care Perception and Parental Stress in a Neonatal Unit. Revista Latino-Americana de Enfermagem, 24, e2753. https://doi.org/10.1590/1518-8345.0710.2753

Bamm, E.L. \& Rosenbaum, P. (2008). Family-centered theory: Origins, Development, Barriers, and Supports to Implementation in Rehabilitation Medicine. Archives of Physical Medicine and Rehabilitation, 89(8), 1618-1624. https://doi.org/10.1016/j.apmr.2007.12.034

Brush, BL, Kirk, K, Gultekin, L \& Baiardi, JM. (2011). Overcoming: A Concept Analysis. Nursing Forum, 46(3), 160-168. https://doi.org/10.1111/j.1744-6198.2011.00227.x

Caqueo-Urizar, A., Rus-Calafell, M., Urzua, A., Escudero, J., \& Guitierrez-Maldonado, J. (2015). The Role of Family Therapy in the management of schizophrenia: challenges and solutions. Neuropsychiatric Disease and Treatment, 11, 145-151. https://doi.org/10.2147/NDT.S51331.

Chadda, R.K. (2014). Caring for the Family caregivers of persons with mental illness. Indian Journal of Psychiatry, 56, 221-227. https://doi.org/10.4103/0019-5545.140616

Chein, W.T., Leung, S.F., Yeung, F.K., \& Wong, W.K. (2013). Current Approaches to treatments for schizophrenia spectrum disorders, part II: Psychosocial Interventions and Patient-focused perspectives in Psychiatric Care. Neuropsychiatric Disease and Treatment, 9, 1463-1481.

Duca, F. (2010). Family Network Support and Mental Health Recovery. Journal of Marital and Family Therapy, 36(1), 13-27. https://doi.org/10.1111/j.1752-0606.2009.00182.x 
Easley, R. (2007). Harmony: A Concept Analysis. Journal of Advanced Nursing, 59(5), 551-556. https://doi.org/10.1111/j.1365-2648.2007.04315.x

Engaging Patients and Families. (2020). American Academy of Pediatrics. https://www.aap.org/enus/professional-resources/practice-transformation/managing-patients/Pages/assessing-familycenteredness.aspx

Family-centered care. (n.d.). Medical Dictionary for the Health Professions and Nursing. (2012). https://medicaldictionary.thefreedictionary.com/family-centered+care

Family-centered care. (n.d.) Medical Dictionary. (2009). https://medical-dictionary.thefreedictionary.com/familycentered+care

Family-centered practice. (n.d.) Child Welfare Information Gateway. https://www.childwelfare.gov/topics/ famcentered/

Foster, K., O'Brien, L., \& Korhonen, T. (2012). Developing Resilient Children and Families when parents have a mental illness: a family-focused approach. International Journal of Mental Health Nursing, 21(1), 311. https://doi.org/10.1111/j.1447-0349.2011.00754.x

Foster, K., Mayberry, D., Rupert, A., Gladstone, B., Grant, A., Ruud, T., Falkov, A., Kowalenko, N. (2016). Family-Focused Practice in Mental Health Care: An Integrative Review. Child and Youth Services, 37, 129-155. https://doi.org/10.1080/0145935X.2016.1104048

Goldfarb, F.D., Devine, K., Yingling, J.T., Hill, A., Moss, J., Ogburn, E.S., Roberts, R.J., Smith, M.A., \& Pariseau, C. (2010). Partnering with Professionals: Family-centered care from the parent perspective. Journal of Family Social Work, 13(2), 91-99. https://doi.org/10.1080/10522150903487081

Grant, A \& Reupert A. (2016). The Impact of Organizational Factors and Government Policy on Psychiatric Nurses' Family-Focused Practice with parents who have a mental illness, their dependent children, and families in Ireland. Journal of Family Nursing, 22(2), 199-223. https://doi.org/10.1177/10748 40716643770

Jolley, J. \& Shields, L. (2009). The Evolution of Family-Centered Care. Journal of Pediatric Nursing, 24(2), 164170. https://doi.org/10.1016/j.pedn.2008.03.010

Heru, A.M. (2015). Family-centered care in the Outpatient General Psychiatry Clinic. Journal of Psychiatric Practice, 21(5), 381-388. https://doi.org/10.1097/PRA.0000000000000097

Hodgetts, S, Nicholas, D, Zwaigenbaum, L \& McConnel D. (2013). Parents' and Professionals' perceptions of family-centered care for children with autism spectrum disorder across service sectors. Social Science and Medicine, 96, 138-146. https://doi.org/10.1016/j.socscimed.2013.07.012

Hutchfield, K. (1999). Family Centred Care: a concept analysis. Journal of Advanced Nursing, 29(5), 11781187. https://doi.org/10.1046/j.1365-2648.1999.00987.x

Leonard, R.A. \& Linden, M. (2018). Family-focused practice for Families Affected by Maternal Mental Illness and Substance Misuse in Home Visiting: A Qualitative Systematic Review. Journal of Family Nursing, 24(2), 128-155. https://doi.org/10.1177/1074840718770612

McNeil, S. (2013). Understanding Family-Centered Care in the Mental Health System: Perspectives From Family Members Caring for Relatives With Mental Health Issues, Social Work in Mental Health, 11(1), 55-74. https://doi.org/10.1080/15332985.2012.720662

Park, M., Giap, T.T., Lee, M., Jeong H, Jeong M \& Go, Y. (2018). Patient and family-centered care interventions for improving the quality of health care: A review of systematic reviews. International Journal of Nursing Studies, 87, 69-83. https://doi.org/10.1016/j.jpurstu.2018.07.006

Park, S. \& Park, K.S. (2014). Family Stigma: a concept analysis. Asian Nursing Research, 8, 165-171. http://dx.doi.org/10.1016/j.anr.2014.02.006 
Parrish, RA \& Chan, E. (2008). Developmental-Behavioral Pediatrics: Evidence and Practice. https://www.sciencedirect.com/topics/medicine-and-dentistry/family-centered-care.

Partnership (2018). Patient Safety. http://www.who.int/patientsafety/implementation/apps/definition/en/

Patient and Family-centered care. (n.d.). Institute for Patient and Family-Centered Care. https://ipfcc.org/bestpractices/sustainable-partnerships/background/pfcc-defined.html

Rose, L.E., Mallinson, R.K. \& Walton-Moss B. (2004). Barriers to Family Care in Psychiatric Settings. Journal of Nursing Scholarship, 36(1), 39-47. https://doi.org/10.1111/j.1547-5069.2004.04009.x

Thompson, C.J. (2018). Commonly used concept analysis methods in nursing: An Introduction to Walker and Avant's 8-step method. https://nursingeducationexpert.com/concept-analysis-methods-walker-avant/

Walker, L.O. \& Avant, K.C. (2005). Strategies for Theory Construction in Nursing (4th ed). Pearson Education.

Wells, N. (2011). Historical Perspective on Family-Centered Care. Academic Pediatrics, 1192), 100-102. https://doi.org/10.1016/j.acap.2011.01.007

Whittaker, N. (2017). Disorders and Interventions. https://books.google.com.ph/books?id=eFFdDwAAQBAJ\& $\mathrm{dq}=$ norma+whittaker+family+centered+therapy\&source=gbs_navlinks_s

Williams, K. (2014). Building on a Culture of Patient and Family Centred Care in the Mental Health Setting, Masters Thesis. Retrieved from ProQuest, (Accession No. 1571419).

Wong. O.L. (2014). Contextual Barriers to the successful implementation of Family-centered practice in Mental Health Care: A Hongkong Study. Archives of Psychiatric Nursing, 28(3), 212-219. https://doi.org/10.1016/j.apnu.2014.02.001

Wong, O.L., Suk Fan Wan, E. \& Lai Tuen Ng, M. (2016). Family-centered care in Adult's mental health: Challenges in Clinical Social Work Practice. Social Work in Mental Health, 14(5), 445-464 https://doi.org/10.1080/15332985.2015.1038413

\section{About the Author}

Iril I. Panes, Ph.D., MA, RN, is a clinical assistant professor of Sultan Kudarat State University (SKSU), Tacurong City, Sultan Kudarat, Philippines. She earned her Bachelor of Science in Nursing at Davao Doctors College, Davao City, Philippines (1992), and her Master of Arts in Nursing at Philippine Christian University, Manila, Philippines (2010). She completed her Doctor of Philosophy in Nursing Science at St. Paul University Philippines System (2020). She is an advocate of mental health and aims to make a difference in the field of mental health nursing. 